\title{
Off and On: China's Principle of Non-Interference in Africa
}

\author{
Adaora Osondu \\ Email osondua@yahoo.com
}

\section{Doi:10.5901/mjss.2013.v4n3p225}

\begin{abstract}
The entry point for this paper is the premise that China's principle of non-interference is one current debated issue in China's contemporary engagement with Africa. Scholars have argued on the implications of this principle for consolidation of democracy, good governance and human rights in Africa. Others have pointed on the good of the principle, asserting that it has become an alternative for African governments to avert the Western imposition of conditionalities and their long procedural routine. The purpose of this paper is not to reiterate the well known gospel on the implications (positive or negative) of the principle but to examine the origin of this principle, particularly in Sino-Africa relations and the consistency or otherwise of China's application of this principle in Africa. This paper with specific reference to Sudan and Zimbabwe seeks to examine the 'off' and 'on' of this principle in China's contemporary relations with Africa. Making use of both primary (interview) and secondary (journals, books, internet materials, memos etc) sources of data, this paper analysed what caused the shift (off) and what caused the maintenance of the stance (on) in China's application of this principle in Africa.The study revealed that China's application of non-interference principle in Africa has not been consistent. China's insisting (switching on) or noninsisting (switching off) on non-interference policy is dictated by its primal national interest. For instance, China's shifting of its stance on non-interference and persuading Sudan to accept the UN force has to do with its overriding interests at the timehosting of the Olympics. Generally, non-interference principle apart from being a principle established in international law also serves as a tool that China sometimes employs to pursue its interests in its relations with Africa.
\end{abstract}

Keywords: China, Non-interference principle, Application, Off, On, Africa

\section{Introduction}

China's principle of non-interference in internal affairs of other states is not a newly formulated principle. Although it dates back to the 1950s, it is one current debated issue in China's contemporary engagement with Africa. It is unlikely for one to come across a study on China's $21^{\text {st }}$ century engagement with Africa without a mention of this principle and its implications for Africa's relations with China; especially its implications for consolidation of democracy and respect for human rights in Africa. China's principle of non-interference in Africa has increasingly drawn public criticisms with few exceptions; those who see it as the best approach in relations with sovereign states and those who see it as a model contrary to Western impositions and encroachment on the internal affairs of African states.

As China continues to maintain an absolute stance (non-interference) in its external relations, debate has been on and on, on what China's contemporary engagement portends for Africa. While Chinese leaders believe human rights are relative, and each country should be allowed to tackle it their own way without external interference, the West views human rights as a global issue that supersedes sovereignty and external interference is to be carried out when it has to do with human security.

To the West, China's principle of non-interference into the domestic affairs of other states is an irresponsible 'see no evil' approach which is bound to undermine human rights and democracy in Africa and European efforts to promote these values, as for example in Darfur and in Zimbabwe (Tull, 2008). China's stance on non-interference principle was blamed for enabling the ruling forces in Sudan to carry out genocide and is considered to serve as a carrot for the dysfunctional government in Angola (Hodel, 2008). But China has argued that attempts by foreign nations to discuss democracy and human rights violate the rights of a sovereign country (Hanson, 2008). China's argument seemed to have gained acceptance with some African leaders. For most African countries that seem to be more concerned with getting rid of Western interference in their domestic issues and preserving national sovereignty, China seems to be an alternative to the Western economic prescriptions that are marred by aid conditionalites and the unnecessary foreign interference that seem to continuously disrupt their national sovereignty (Mutasa, 2009).

Undoubtedly, China's engagements with Africa especially in countries like Sudan and Zimbabwe have generated a lot of questions and debates on China's principle of non-interference. This paper examines the origin of this principle and 
tries to establish how China has used it in its early contact with Africa on to the present time. Key questions addressed are; is the application of this principle consistent (from China's early contact with Africa on to the present time)? In other words, has the principle been on or off? What then caused the 'off and on' of China's non-interference policy in its relations with Africa are all what this paper seeks to unravel.

This paper is then organised as follows. Section II provides the background/origin of Chinese principle of noninterference and varied notions/interpretations of the principle. Section III examines the application of this principle in early Sino-African relations and possible reasons for the 'off or on switch.' Section IV with reference to countries like Sudan and Zimbabwe examines its application (the consistency or otherwise) in the contemporary Sino-Africa relations. Section V drawing from the analysis from section III and IV makes the final conclusion.

\section{Origin of Chinese Non-Interference Principle with Varied Notions/Interpretations of the Principle}

Since the emergence of states with the treaty of Westphalia in 1948, international relations have been based on sovereignty, from where the principle of non interference was derived. Traditionally, sovereignty has been designated as the independence and supreme power of states to exercise their power over their respective territories. Sovereignty is what Milojevic (2000) termed 'the existence of exclusive internal competence of state which states must not interfere in.' Rousseau (1974) cited in Milojevic (2000) called it the existence of 'competence discretionaire' of a state. Noninterference is the counterpart principle of sovereignty and it usually encompasses all matters in which each state is permitted by international law to decide and act without intrusions from other sovereign states (IDRC, 2004). Thus, the principle of non-interference is the mirror image of the sovereignty of state (Wood, 2007). Non-interference stems from the traditional notions in international relations of equality of the sovereignty of states and the consequent right to exclusive sovereignty (Robin, 2000). Affirmately, IDRC (2004) noted that 'the principle of non-interference in affairs that are within the domestic jurisdiction of states is the anchor to state sovereignty within the system of international relations and obligations.'

It is a principle supported by Customary International Law and is well documented in the Charter of United Nations (Robin 2000), that almost every independent state subscribes to. Non-interference is one of the principles in international law that has been preserved in international organisations as well (Milojevic, 2000). In accordance with Article 2 (1) of the UN Charter, the world organization is based on the principle of the sovereign equality of all member states (IDRC, 2004). Within the Charter of the UN, there is an explicit prohibition on the world organization from interfering in the domestic affairs of member states.

For China, non-interference became weighty in the 1950s. Following US extended protection to the defeated nationalist Kuomintang - Taiwan government (currently referred to as the Republic of China) and its later interference in Korean War, China had to formalise the principle of non-interference in its external relations. Indeed, China saw the step by the United States to protect Taiwan as 'interference in Civil War' (Ogunsanwo, 1974). What is more, with the US subsequent policy of isolating the Communists throughout the world, it was clear to China that the way out is to spell out this principle in its external relations to avoid external interference, and more importantly to disarray fears from its neighbours about suspicion of itself interfering in their affairs. Thus, in order to clear any suspicion of hegemonic behaviour for its neighbours, China first included 'this principle' in what it called 'five principles of peaceful co-existence' in Sino-Indian trade agreement signed in 1954. The five principles are

1. China supports the African and Arab peoples in their struggle to oppose imperialism, old and new colonialism and to win and safeguard national independence.

2. It supports the pursuance of a policy of peace, neutrality and non-alignment by the governments of the African and Arab countries.

3. It supports the desire of the African and Arab peoples to achieve unity and solidarity in the manner of their own choice.

4. It supports the African and Arab countries in their efforts to settle their disputes through peaceful consultations.

5. It holds that the sovereignty of the African and Arab countries should be respected by all other countries and that encroachment and interference from any quarter should be opposed.

These principles of peaceful co-existence with non-interference being one of them were wholly accepted by India, and the two countries pledged to maintain them in their relations. The document was widely publicised, and it heralded a new peaceful China whose attitudes would make the contemporary American efforts to form an anti-Communist united front in Asia superfluous and irrelevant (Ogunsanwo, 1974). This policy initiative by China was carried on to the Bandung Conference of 1955, in Indonesia; the first most important International Conference held by Asian and African countries, 
'without the participation of any Western colonial power' (Qiutian, 2005) to chart their course for development and liberation from colonialism and imperialism. The ten-point declarations formulated at the Conference were built upon the Chinese five principles of peaceful coexistence. As Qiutian (2005) noted, the well-known ten principles of Bandung are the most important agreement reached by the Bandung Conference as an elaboration and development of the five principles of peaceful coexistence.

Being that Bandung Conference created an avenue for China to link up with Africa officially and with the contact China made with Gamal Abdul Nasser of Egypt (sole African important figure at the Conference), China and Egypt established diplomatic relations in 1956. With many African countries gaining their independence by 1960 (seventeen African countries became independent in the year 1960, which is known as the 'year of Africa'), Zhou Enlai embarked on a tour of Africa in 1963 and early 1964. Premier Zhou in that visit proposed the same five principles of peaceful coexistence to Africa together with the eight principles governing China's aid to developing countries as the basic political and economic norms for developing Sino-African relations. Maintaining these principles with Africa dating to the Bandung Conference of 1955, Beijing staunchly supports the inviolability of African state sovereignty, noninterference in internal affairs, and the need for postcolonial nations to stand up to outside "bullying" and "hegemonism"(Gill, Huang and Morrison, 2007). Thus, China has historically held to a strict interpretation of sovereignty and professed its adherence to peaceful coexistence with other nations (Thompson, 2006).

Nonetheless, 'the principle of non intervention is also well established in contemporary international law' (Wood, 2007). It is reflected in many treaties, such as the Charter of the Organization of American States and the Constitutive Act of the African Union. The International Court of Justice has reaffirmed in many occasions that non intervention principle is part of customary international law. Article 2.7 of the Charter of the United Nations provides that:

"Nothing contained in the present Charter shall authorize the United Nations to intervene in matters which are essentially within the domestic jurisdiction of any state or shall require the Members to submit such matters to settlement under the present Charter."

The concept lies at the heart of both customary international law and the United Nations (UN) Charter and remains both an essential component of the maintenance of international peace and security and a defence of weak states against the strong (IDRC, 2004).

However, if non-intervention is well established principle, why the varied notions? According to Ginn (n.d) there is a better reading of non-interference in harmony with international law; and it means that countries are prohibited from 'coercively' intervening in each other's internal affairs. This reading is in line with the major non-interference case (concerning Nicaragua and United States) held by International Court of Justice that drew the line between permissible and impermissible interference. In military and paramilitary activities in and Against Nicaragua, the International Court of Justice held that United States violated international law by providing funds and training to the Contra Rebels who sought to violently overthrow the Nicaraguan government; however, the court also held that a trade embargo, cessation of economic aid, and other economic measures did not violate the principle on non-interference (Ginn, n.d). The Court maintained that there are 'matters in which each state is permitted, by the principle of state sovereignty to decide freely' (Wood, 2007) and as such should not be interfered with. And also there are ways in which interference could be applied that would not violate the principle or sovereignty of a nation. Apparently, in International Court of Justice's decision, what is prohibited is 'dictatorial or coercive' interference and not absolute non-interference.

The interpretation of this principle still remains unclear and as such different views have continued to emerge. There are those I call the contingent thinkers (those that view non-interference as no longer absolute and could be altered by events, circumstances, especially when it has to do with human security or rights) and the absolutists (who view noninterference as absolute and could not be altered at all even in face of human rights abuse).

Given the changes in international relations, especially with United States as the sole superpower, new perceptions have emerged concerning the principle. Jones (2009) noted that after the cold war, non-interference became part of a political confrontation with the West, whose liberalising project threatened established domestic power relations.

The growing interest in the security of people everywhere (human security) has questioned the idea of absolute sovereignty as argued by the Contingent thinkers. They maintained that 'international actors have a responsibility to come to the aid of populations at risk in the face of repressive or weak states' (1DRC, 2004). Reisman (1990) pointed that on a scale of values, the sovereignty of a state does not stand higher than the human rights of its inhabitants. Hence, 'the view emerging from many quarters is that sovereignty is no longer sacrosanct' (Chopra and Weiss, 1992). The argument is that 'in today's globalising world, it is generally recognised that cultural, environmental, and economic influences neither respects borders nor require an entry visa' (IDRC, 2004). Therefore invoking non-interference in issues that states are supposed to cooperate and offer solutions is what Ginn (n.d) report called 'using non interference as a protective screen 
for regimes that are acting in improper way.' Such actions taken by the Security Council which most times are seen as 'intervention' are believed by the Contingents to have 'risen from the 2005 World Summit Outcome that confirms that enforcement actions to protect populations from genocide, war crimes, ethnic cleansing and crimes against humanity are within the Security Council's powers under Chapter VII' (Wood, 2007).

For the absolutists', the issue of human rights should not change the principle that upholds the sovereignty of a state. It is argued that, "if a country is stripped of its right to independence and sovereignty, how can its people realise their human rights'?(Thang, n.d). Thang (n.d) argued that 'to say that human rights rank above sovereignty is only a disguise used by neo-colonialists to intervene in internal affairs of sovereign countries.' In furtherance of this argument, Thang (n.d) maintained that 'a violation of national sovereignty means trampling upon the human rights of the entire people in that country.'

Most developing countries, especially Association of South-East Asian Nations (ASEAN) still maintain that noninterference is absolute. Scholars of Southeast Asia regionalism concur that ASEAN states hardly or hardly ever interfere in internal affairs of each other or of other states (Jones, 2009). Apparently as Jones (2009) noted 'non-interference is the single most important principle underpinning Asian Regionalism', even though 'it has been blamed for arresting regionalism' (Acharya, 2007), which evident in ASEAN being unable to confront important issues like military regime in Myanmar and humanitarian crisis in East Timor (Rahim, 2008). ASEAN strict adherence to non-interference may partially explain the bases for China's consistent invocation of the principle, opposition and abstaining from any move to alter interference, even in human rights violations. China and Russia had vetoed many actions by Security Council, for example the issue of UN intervention in Myanmar (Wood, 2007). China and Russia also vetoed the move by the international community to sanction Sudanese government during the Darfur conflict. The reason given by China and Russia was that 'according to the United Nations Charter, it is only those questions that constitute threats to international peace and security that warrant discussion by the Security Council' (Wood, 2007) and they believe situations in country like Myanmar, Sudan does not pose any threat to international or regional peace. China and Russia have consistently argued that 'the collective efforts by the UN to deal with internal problems of peace and security, and gross violations of human rights, including genocide, have therefore run against the grain of the claim to sovereign status as set out in the Charter (Wood, 2007). For China, sovereignty is seen as the common denominator among all nations regardless of other factors, and fundamentally holds that all countries should be equal and no country has the right to dictate the sovereign affairs of others. China is one of the leading countries that reject outright, any notions of human rights taking precedence over sovereignty, insisting that, "human rights essentially fall within the sovereignty of a country." In bilateral relations, an independent, non-aligned and self reliant policy based on the five principles of peaceful coexistence is asserted as the centre piece of Chinese foreign policy (Kim, 1984).

The controversy on the absolute or contingent nature of the principle continues on and on, with diverse understanding on the use of the principle; making the interpretation of the principle ambiguous. It is important further research dwells and clarifies more on the area where interference should come in and where it should not.

\section{China's Non-Interference Policy in Africa from the 1960s: Off or On?}

In 1963 when Premier Zhou Enlai led China's first highlevel delegation to Africa, He carried the message that China and Africa shared a common experience and could build a new pattern of what would be later known as South-South cooperation, with non-interference policy being a recurrent theme. The visit made by Zhou won the favour of most Africans and its policies widely accepted. As El-Khawas (1973) pointed, among Africans there were widespread interests in Zhou's tour since he was the first such important foreign leader to visit their continent.

China's sensitivities to perceived external interference particularly in the context of Taiwan and Tibet, led it to conceive of sovereignty in traditional Westphalian terms (Rafferty, 2010). Possibly, 'this principle of noninterference has served to safeguard China's own sovereign rights' (Anshan, 2007). But has China maintained non-interference principle in its foreign relations, especially in relations with Africa? Has it been consistent in the application of this principle from the time it was enunciated in the 1950s?

More than thirty years now, El-Khawas (1973) did a study on 'China's Changing policy in Africa', and presented China's role in Africa from the 1960s as aider of revolutionary groups. At the advent of Sino-Soviet rift, China's interest in Africa made China to become more interested in subduing Soviet's influence than following the gospel of the principle of non-interference. Throughout that early period, the Chinese were acting largely as a force supplementary to the Soviet Union's activities (Tareq, 1971). The burnishing of China's credentials as the main revolutionary power depended on winning more support in the developing world than in the Soviet Union (Segal, 1992). The period of Sino-Soviet rift was 
one of the times that China's principle of non-interference in internal affairs of other states was put to a test. China was accused of aiding revolutionary groups in Africa, training them for guerrilla warfare and attacks, which Africans leaders invariably saw as interference. In the Congo Crisis of 1964, China was accused of providing arms and training to members of the National Liberation Committee based in Congo Brazzaville led by Pierre Mulele. Peking's (now Beijing) affiliation with revolutionary groups and interference in affairs of Africans frightened a number of African leaders as they began to express their grave concerns over Chinese activities. President Felix Houphouet-Boigny of Ivory Coast, for instance, voiced then that "........ the peril that menaces Africa today is the yellow-tinted Communism of Peking"( Cited in El-Khawas, 1973). Most African leaders saw Chinese activities in that period as nothing short of interference or 'intervention in their internal affairs.' The then President Hamani Diori of Niger called a meeting of the Common Organisation of African and Malagasy States (OCAM) to work out a plan to cope with Chinese threat. This led to Chinese diplomats being declared persona non grata in ten states of the OCAM, including Dahomey, Ivory Coast, Madagascar and Senegal (El-Khawas, 1973). Four other African countries (Burundi, Central African Republic, Ghana and Tunisia) broke diplomatic relations with China in 1966. Kenya expelled Chinese diplomats during the period (George, 1966). In fact, Kenya's governing party, Kenya Africa National Union (KANU) on learning of Chinese support to the opposition Party, the Kenya People's Union, issued a statement warning:

"Events in Africa during 1966 and continuing instability in some parts of the continent make it easy, and in fact inviting, for some countries to feel that they can meddle in the affairs of African states. Forces are anxious to sow the seeds of suspicion among neighbouring states. Confusion and instability in Africa benefit such forces. It is important that the African countries be on their guard against the intrigue and manipulations of these forces which only purpose must be to destroy that which we are trying to build. Any party which relies on the inspiration and support of outsiders cannot be regarded as a genuine nationalist organisation and must be looked upon with suspicion by the people of this country (Cited in Larkin, 1971)"

Though 'China out-rightly denied such accusations' but diplomatic relations nevertheless deteriorated (El-Khawas, 1973). The height of which was Africa's severing of diplomatic relations with China. To sever existing relations is a highly charged and symbolic act, since most states do not effect a diplomatic rupture without intending to show profound disapproval of other country; the breaks between China and African countries seem to imply that China committed grave and improper deeds, forcing African retaliation (Larkin, 1971). China passed through the decade of the 1960s under a cloud of suspicion over its radical revolutionary posture and competition with the former Soviet Union for allies (Bukarambe, 2005). Rafferty (2010) affirmed that the principle was regularly violated by the support China lent to revolutionary movements across Africa and Asia in the 1960s and 1970s. Arguably the principle of non-interference was switched off by China from the record of China's role in the 1960s. It was when diplomatic relations was ruptured with many African countries that China had to revisit its non-interference policy in Africa.

One could argue on one hand, that there is possibility that China has learnt from its experience to follow strictly the principle of non-interference (to maintain normal relations with all types of regimes- autocratic or democratic) or risk African countries for Taiwan (Taiwan is an inalienable part of China as China has maintained and must not gain any recognition from any country; it is important to note that it was Taiwan's case that made China to expound the 'One China Policy' in its foreign relations). On the other hand, it could also be argued that the switching off the principle at that period could be that there was something more important than the principle (the desire to gain more influence than Soviet Union; and win more allies).

But knowing fully well that African votes count a lot for her in UN, China had to 'switch on' the principle of noninterference to avert more diplomatic rupture in its relations with Africa. China's 'diversion of approach' in its African relations became evident when the then Mali's President Modibo Keita was ousted in November 1968. China promptly contacted the military junta .....despite the fact that Modibo had been one of China's few friends in Africa (El-Khawas, 1973). The 'switching on' of the application of the principle by China apparently contributed in many African countries support for China's regaining of its seat in UN Security Council in 1971. On the direct vote on the resolution concerning China's re-admission, seven African nations shifted their voting positions, all in directions favourable to China. Rwanda, Sierra Leone and Togo switched from "no" to "yes", while Botswana, Cameroun, Senegal and Tunisia changed from abstention to affirmative, with no abstention recorded at all among the African votes. 26 out of the 76 votes in the United Nations came from Africa. China has continued to profess non-interference in Africa.

\section{China's Non-Interference Policy in Africa in the 21st Century: Off or On?}

Although the official drivers of China's African approach had been dramatically redefined by the turn of the $21^{\text {st }}$ century, the political relationship, on the surface at least retained some similarities to what was seen in the 1960s and 1970s 
(Kobus and Dirk, 2006). China's principles of peaceful coexistence constituted a whole set of China's policy in expanding Sino-African cooperation and laid the foundation for new type of relationship (Gongyuan, 1996). President Hu stated in his keynote speech at the CCP's $17^{\text {th }}$ National Congress in Beijing in October 2007 that:

\begin{abstract}
"Politically, all countries should respect each other and conduct consultations on an equal footing in a common endeavour to promote democracy in international relations. Economically, they should cooperate with each other, draw on each other's strength and work together to advance economic globalisation in the direction of balanced development, shared benefits and win-win progress" (cited in Lanteigne, 2009)
\end{abstract}

Following the unfavourable times of China-Africa relations (for instance the diplomatic rupture with some African countries in the early 1960s) and the favourable times, for instance African support at the UN, China revisited its African policy. China needed to reassure African leaders of its support on fostering its development and also its position on noninterference as the basis of its foreign relations. China continued to upheld the view that 'the five principles of peaceful coexistence are not only the basic norm of international relations but also the essential means of ensuring international peace and security' (Kim, 1984).

In 2000, a new China-Africa Cooperation Forum (the first of its kind in Sino-Africa relations) agreed on a joint economic and social program, one that is grounded on the traditionally defined doctrine, "the five principles of peaceful co-existence." Also in 2003, Ambassador Zhang Yishan, Deputy Permanent Representative of China to the United Nations, summed up China's non-interference posture when he stated:

'Externally imposed conditions do not offer genuine solutions to African problems; in many instances, liberalisation, privatisation, market reform and other re-adjustment programs not only are incapable of promoting African economic growth but on the contrary have created serious social problems.' (cited in Thompson 2006)

Yishan went on to say that 'the international community should therefore fully acquaint themselves with the real circumstances of the African countries and respect their sovereign choices' (cited in Thompson, 2006). On the year marking China's establishment of diplomatic relations with Africa in 2006, China published a major policy document outlining the new directions of its Africa policy. The Africa policy document is firmly in line with the same five principles of peaceful co-existence. The document pointed two fundamental principles of Chinese foreign policy; the principle of noninterference in internal affairs of other states and the 'One China Principle' (Tjonneland et al, 2006).

On many subsequent international occasions, China has continuously committed itself publicly that it respects the rights of African people in choosing their own route to development and way of life and China will never interference in the internal affairs of any sovereign countries (Susu, 2006). In the author's interview with Mr Frank, Chinese Country Attache at the Commercial Section, Embassy of People's Republic of China, Lagos, Nigeria, on 5 November, 2011, Mr Frank maintained 'that the sovereignty of any country takes precedence over any human rights and China is not prepared to interfere in any sovereign state. He went on to say that China believes in assisting Africa to develop and not on the preaching of human rights without food. To Frank, 'issues in Sudan, Zimbabwe, Angola etc that China are accused of fuelling are all African internal problems that China could not have interfered with; China only assists Africa in areas where Africa calls for help.'

Possibly, China's re-arrival in Africa with great emphasis on non-interference could also be due to the support China received from most African countries ('who did interfere in China's affairs') in the wake of Tiananmen Square Crack down in 1989. Many African States rallied to Beijing's defense after Western nations criticised and imposed sanctions on China (Feinstein, 2007). Also Africa has supported China in human rights issues at the United Nations. Over the past decade, human rights proposals against China were defeated 11 times at the United Nations, which Anshan (2007) noted that 'without African nations support, China could not have defeated those proposals.' Ordinarily China's human rights issues being debated at the UN would have made China to realise that it has its own domestic problems of human rights and corruption that make it difficult for her to criticize others.

China's non-interference as explained above is not a new principle that China just put forward in the $21^{\text {st }}$ century but arguably its application has become more pronounced at the moment. China's current roles in countries like Sudan and Zimbabwe have become more contentious because of the issue of China's principle of non-interference. An assessment of how this principle is currently applied (off and on) by China in these two countries is done below.

\title{
1.1 Sudan
}

Sino-Sudan relation is not new. Though not independent at the Bandung Conference of 1955, Sudan through its 
participation at the Conference shared the 'Bandung Spirit' and ten principles that emanated from the Conference, which was built on Chinese five principles of peaceful coexistence. After gaining its independence on $1^{\text {st }}$ January 1956, Sudan, on $4^{\text {th }}$ February 1959 became the third African country to establish diplomatic relations with China after Egypt (May 30, 1956) and Morocco (November 1, 1958). Sudan was among the ten African countries visited by Zhou Enlai in his first tour of Africa. Zhou Enlai received friendlier welcome in Sudan in 1964 (Tareq, 1971). The relations between China and Sudan have continued to strengthen following China's economic development and the need for oil which Sudan is endowed with. Beijing has been a long standing investor in Sudan's energy sector since 1996. Its investment in Sudan is said to be 'the largest African international investment made by China in the energy sector' (Frynas and Paulo, 2007). China is the biggest investor in Sudan's $\$ 15$ billion 932-mile oil pipeline to Port Sudan on the Red Sea where China is also building a tanker terminal(Malaquias, 2007). Although Angola provides China with most of its oil, Sudan hosts China's biggest oil investment overseas. Considering that Sudan only began exporting oil in 1999, there is every chance that Sudan will surpass Angola in supplying China with oil in the future. Currently, roughly 60 percent of Sudan's oil is destined for China, making up 12 percent of Chinese oil imports (Thompson, 2007).

China's current relations with Sudan have been criticised based on China's principle of non-interference. This criticism arose because despite the war and the then human rights violations in Darfur, China maintained its stance on non-interference in Sudan's affairs. To underscore the point, Chinese officials have repeatedly argued that attempts by other countries to link positions on democracy and human rights to economic integration violate the rights of sovereign countries (Baseda et al, 2008). The Deputy Chinese Foreign Minister when interviewed on the situation in Sudan in 2004 was quoted to have said:

\section{Business is business. We try to separate politics from business.... Sudan's situation is an internal affair and we have no right to impose upon them. You (the West) have tried to impose a market economy and multiparty democracy on these countries which are not ready for it. We are also against embargoes, which you have tried to use against us (cited in French, 2004)}

In September 2004, the United Nations Security Council (UNSC) passed Resolution 1564 which condemned the mass killing of civilians in the Darfur region but stopped short of imposing sanctions if Khartoum did not act to stop the killing because China abstained from the vote and threatened to veto any further move to impose sanctions (Sautman and Hairong, 2007).

Until 2006, China had argued against attempts by the United Nations to punish the government of Al-Bashir for the then conflict in Darfur. China has consistently pointed that it does not 'mix business with politics.' Although the phrase 'business' remains ambiguous. It depends on what China means by its 'business' at a particular time. It could be where its interests lie most. For instance, China has large investment in Sudan's oil sector and would not want to compromise that. It could also be that China craves more for economic development and for now, not political development as was pointed by Mr Frank the Country Attache at the Embassy of the People's Republic of China in an interview with the author; and that could be the reason China's domestic economy booms and its human-rights dooms. Besides, China's maintaining of non-interference even in gross human rights violations in countries like Sudan could be China's way of making sure that diplomatic relations are not ruptured. Generally, if China had decided to support opposition groups for instance in Sudan's conflict, this may result to severing of diplomatic relations (which China would not want to happen again as seen in its early contact with Africa, for as the saying goes 'once beaten, twice shy'). And rupture of diplomatic relations may even cost China losing such country to Taiwan, an important foreign policy objective that China is struggling to counter.

Arguably, China's national interests and foreign policy objectives take precedence in decisions. As Mark (2008) pointed the principle of non-interference is often seen especially in relation to Sudan and Zimbabwe, merely as a cynical cloak for the pursuit of China's national self-interest regardless of human rights and good governance issues.

It is noteworthy that China's stance on interfering in Darfur's conflict was shifted later in 2006. As the international calls for potential Olympic boycott (China was to host 2008 Olympic) over Darfur became more strident, Beijing in the autumn of 2006 shifted its stance and had to persuade the Sudanese government to accept a tandem UN-African Union (AU) peacekeeping force under an agreement in Addis Ababa (Lanteigne, 2009). To convince Sudan to accept the UNAfrican Union peacekeeping force, China announced the cancellation of Sudanese debt and promised to build Al-Bashir a presidential palace (Shinn, 2007). Given China's interest in hosting the Olympic, China applied different strategies to make Sudan agree. In March 2007, China's main Economic Planning Agency, the National Development and Reform Commission, released a public document in conjunction with the Ministry of Foreign Affairs and the Ministry of Commerce, noting that Sudan had been removed from the latest list of countries with preferred trade status (McGregor, 
2007). According to the announcement, Beijing would no longer provide financial incentives to Chinese companies to invest in Sudan. This latest move appeared to be a signal of Chinese disaffection with Al-Bashir's unwillingness to comply with his commitments to implement the Annan Plan (Gill et al, 2007). But more importantly China had to apply these means to make sure nothing comes in the way of its hosting of the Olympic, which was already then labelled 'the Genocide Olympic.' This shift from China 'was seen as unsurpassed importance Beijing attached to the success of its hosting of the Olympic games in 2008' (Reeves, 2007). Apparently, China realised the importance of the Olympic to project its image and economic development to the world. Hosting Olympic invariably at that time is a more paramount interest than the economic interest (oil) in Darfur (though oil is still very important). But China has Angola (its major oil market in Africa) to substitute for Darfur's oil.

Prior to the 2008 Olympic, Beijing has been very emphatic about maintaining its sovereignty and has resisted international calls for greater democracy and human rights, arguing that such areas must be addressed by 'Beijing only and at a pace which China itself is most comfortable' (Lanteigne, 2009). Thus, China in the real sense of it addressed Sudan's issue at the time and pace it was most 'comfortable or 'favourable as the case may be. It is obvious that an overriding interest resulted to shift in China's position in Sudan. And this is what I called 'switching off' of non-interference principle in Sudan. To Stephanie Kleine-Ahlbrandt and Andrew Small, cited in Hanson (2008), 'Beijing's recent handling of the situation in Sudan shows that it is learning the limitations of non-interference.....' Thompson (2007) emphasises that China's "non-interference" is Orwellian language for a malleable concept that is prescribed when it best serves China's purpose, economic gain.' For instance, in the Zambia's 2006 presidential elections, the leading opposition candidate, Michael Sata, ran on an anti-China platform. In a strong contradiction to the spirit of China's foreign policy approach (non-interference), China threatened to cut all economic ties with Zambia if Sata won the election. Thompson (2007) pointed, 'the case demonstrated that China has very little patience for internal politics that would jeopardize their economic interests.' It is important to note that China's shifting of its stance in Sudan was not total as China's arms sales never stopped. The major shift was to give way to a more primal interest at the time.

\subsection{Zimbabwe}

Zimbabwe is another case in point. There has been longstanding relationship between China and Zimbabwe dating from the early Chinese support of the opposition leader and now President Mugabe (Lanteigne, 2009). The largest project China undertook in Africa in the 1970s was Tan-Zam railway construction. What is more, China's support for Zimbabwe spans over three decades. During Zimbabwe's Unilateral Declaration of Independence, China provided logistical training, arms and funding support to Mugabe's Zimbabwe Africa National Union (ZANU) liberation front. When Mugabe was elected he disbanded the rival political party and, with the support of China and the Shona speaking majority, has remained in power for over 25 years(Butts and Bankus, 2009).

After Americans and Europeans withdrew from the country due to the government's destructive land reform program and poor human rights record, China stepped in, ready to work with the resource-rich African nation. Zimbabwe has the second largest deposit of platinum in the world, which is of great interest to China. China's policy of noninterference in the domestic affairs of other states is central to its appeal to Mugabe as a trading partner. China has been very active in support of Zimbabwe, which is "patria non grata" in the West (Rourke, 2006).

China's link with Robert Mugabe has triggered much debate on the implications of China's principle of noninterference for good governance and human rights protection in Zimbabwe and Africa as a whole. For almost a decade now, the Mugabe government had come under mounting international criticism both for an increasingly authoritarian stance, suppression of personal freedoms and for widespread economic mismanagement and draconian land reform which exacerbated poverty levels in the southern African country (Lanteigne, 2009). The West imposed sanctions on Mugabe and China being a 'non-interference actor' offered an alternative for Mugabe. Mugabe has since 2003 adopted a 'look east policy.' In 2008, following the widespread irregularities during the general election, the West took up Mugabe's case again in United Nations and was ready to impose sanctions when China and Russia vetoed it. China and Russia argued that the issue was an internal matter outside of the United Nations Security Council jurisdiction and best solved by talks between the government and opposition leaders (Lanteigne, 2009). Increasing isolation and pressure from the West have caused Zimbabwe to develop close relations with China........where China now provides Mugabe with a lifeline to resist Western sanctions and criticism (Watts and Meldrum, 2005).

China provides for Mugabe's military needs without interfering in his internal affairs and praises Mugabe as a man of great achievements, devoted to world peace and a good friend of the Chinese (Dickie and Reed, 2005). China's principle of non-interference is yet to experience any shift (what I called 'switching off') in Zimbabwe. 
It is expected that China's stance in Zimbabwe will shift with time, with the arrival of a more paramount interest (be it political or economic) as seen in Sudan. Gill et al (2007) have pointed that adhering to a formal policy of noninterference and putting it into consistent practice will be difficult and likely clash over time with deepening Chinese interests as China will increasingly face mounting pressures to support humanitarian intervention in Africa. To Tjonneland et al (2006), it is extremely difficult to navigate safely between a foreign policy that must at the same be in the service of economic modernisation... be a constructive partner in international development, and simultaneously stick to the principle of non-intervention.

Ordinarily, adhering completely with non-interference is irreconcilable with China's paramount interest (whether political or economic interests in Africa).

\section{Conclusions}

Undeniably, Chinese principle of non-interference is not a new principle in Sino-Africa relations. Though the principle remained unchanged, its application has failed to be consistent in its relations with Africa. The paper has revealed that both in China's early and present contact with Africa, the application of non-interference principle has not been entirely consistent. In the early times, the principle of non-interference was almost not in existence in Sino-Africa relations. The principle as argued by the author 'switched off'; and this switching off was mainly caused by the Sino-Soviet rift; China wanted to win more allies than the Soviet Union and it had to switch off the principle to aid revolutionary groups in Africa.

In its $21^{\text {st }}$ century involvement with Africa, the principle has gained much significance in Sino-Africa relations. But what is revealed from the study is that in both China's $20^{\text {th }}$ and $21^{\text {st }}$ century relations with Africa; the principle does not take prominence over China's national interests at any time. China 'switches on' the principle until more paramount interest (political or economic interest) arises. In the case of Sudan, China later shifted its stance on non-interference. China saw the importance of hosting the Olympic and had to shift its stance on persuading Sudan to accept the UN force. The hosting of Olympic became more paramount than oil (Sudan's oil). Clearly, China's principle of non-interference had undergone series of shift, primarily due to China's pressing or overriding interest at the time.

Conclusively, notwithstanding that China continues to reiterate the gospel of non-interference, its application has not been fully consistent in its relations with Africa as its application is tied to China's overriding national interests at any time. Thus, it is important further study examines the role China's national interests play with regards to its foreign policy especially its African policy.

\section{References}

Acharya, Amitav. (2007). 'East Asia's Arrested Regionalism' Paper Presented at Asia Studies Seminar, St Anthony's College Oxford, 23 February 2007

Anshan, Li. (2007). China and Africa: Policy and Challenges. China Security, Vol.3, No.3, World Security Institute

Baseda, Hang; Wang, Yang and Whalley, John. (2008). China's Growing Economic Activity in Africa. National Bureau of Economic Research, Working Paper, http://www.nber.org Accessed April 10, 2007

Bukarambe, Bukar. (2005). Nigeria-China Relations: The Unacknowledged Sino Dynamics. Nigeria Institute of International Affairs, Lagos

Butts, Kent H. and Bankus, Brent. (2009). China's Pursuit of Africa's Natural Resources. Centre for Strategic Leadership, U.S. Army War College, June, Vol. 1-09

Chopra, Jarat and Weiss, W Thomas .(1992). "Sovereignty Is No Longer Sacrosanct: Codifying Humanitarian Intervention," Ethics and International Affairs

Dickie, Mure and Reed, John. (2005). "China Hails Mugabe's Brilliant Diplomacy". Financial Times, July 27. http://www.news.ft.com Accessed July 28, 2005

El-Khawas, A. Mohammed. (1973). China's Changing Policies in Africa. A Journal of Opinion, Vol.3, No.1, pp.24-28, http://www.jstor.org Accessed August 15, 2009

Feinstein, Lee. (2007). China and Sudan. http://www.tpmcafe.com Accessed September 19, 2007

French, Howard (2004) "China in Africa: All Trade and No Political Baggage," http://www.globalpolicy.org Accessed May 5, 2007

Frynas, Jedizej George and Paulo, Manuel. (2007). A New Scramble for Africa Oil? Historical, Political, and Business Perspectives. African Affairs, The Journal of the Royal African Society Vol. 106, No. 423

George T.Yu. (1966). China's Failure in Africa, Asian Survey, Vol. 8, pp.461-468

Gill, Bates; Huang, Chin-Hao and Morrison J. Stephen. (2007). China's Expanding Role in Africa: Implications for the United States. A Report of the CSIS Delegation to China on China-Africa-U.S Relations, November 28-December 1, 2006

Gill, Bates; Huang, Chin-Hao and Morrison, J. Stephen. (2007). Assessing China's Growing Influence in Africa. China Security, Vol.3, No.3 
Ginn, David. (n.d). The Abused Notion of Non-Interference. Being A Report Prepared For Asean Inter-Parliamentary Myanmar Caucus. http://www.aseanmp.org Accessed October 10, 2010

Gongyuan, Chen. (1996). Towards A 21 ${ }^{\text {st }}$ Century Sino-African Relationship. Foreign Affairs Journal, The Chinese People's Institute of Foreign Affairs, December, No.42

Hanson Stephanie. 2008. China, Africa and Oil. Council on Foreign Relations. http://www.cfr.org Accessed December 18, 2009

Hodel, Mikel. (2008). The Scramble for Energy: China's Oil Investment in Africa. The Journal of International Policy Solutions, Vol.9

IDRC. (2004). State Sovereignty. http://www.idrc.ca Accessed September 8, 2010

Jones, Lee. (2009). ASEAN's Unchanged Melody? The Theory and Practise of 'Non-Interference in South East Asia. Paper Presented for International Boundary Research Unit's 'The State of Sovereignty' conference, University of Durham, 1-3 April 2009.

Kim, S. Samuel. (1984). China and the Third World: In Search of a Neorealist World Policy, In China and the World, ed. Westview Press. Kobus, Van der Wath and Dirk, Kotze. (2006). China and Africa: A Neglected Opportunity. African Analyst Quarterly

Lanteigne, Marc. (2009). Chinese Foreign Policy: An Introduction. Routledge, Taylor and Francis Group, London and New York

Larkin, D. Bruce. (1971). China and Africa (1949-1970). University of California Press, California

Malaquias, Assis. (2007). Thirsty Powers: United States, China and Africa's Resources. http://www.africacenter.org Accessed May 2 , 2010

Marks, Stephen. (2008). Understanding China's Strategy: Beyond Non-Interference. http://www.pambazuka.org Accessed April 5, 2010

McGregor, Richard. (2007). "Iran, Nigeria, Sudan off China incentive list," Financial Times, March 2, 2007, http://search.ft.com

Milojevic, Momir. (2000). The Principle of Non-Interference in Internal Affairs of States. Journal of Law and Politics, Vol.1, No.4, pp.427447

Mutasa, C. (2009) 'Aid Effectiveness and the Question of Mutual Accountability' in Abbas, H and Niyiragira, Y. 2009. Aid to AfricaRedeemer or Coloniser?, London, Pambazuka Press

Ogunsanwo, Alaba. (1974). China's Africa Policy (1958-1971). Cambridge University Press

Qiutian, Lu. (2005). Carrying Forward the Spirit of Bandung Conference and Steadfastly Following the Path of Peaceful Development. The Chinese People's Institute of Foreign Affairs, No.75

Rafferty, Tom. (2010). China's Doctrine of Non- Interference Challenged by Sudan's Referendum. China Brief, Vol. 10, Issue 25

Rahim, Lily Zubaidah. (2008). 'Fragmented Community and Unconstructive Engagement: ASEAN and Burma SPDC Regime', Critical Asian Studies, 40:1

Reeves, E. (2007). China, Darfur and the Olympic: Tarnishing the Torch? http://www.dreamfordarfur.org Accessed June 5, 2009

Reisman, W.Michael. (1990). "Sovereignty and Human Rights in Contemporary International Law," American Journal of International Law

Robin, Ramcharan. (2000). ASEAN and Non-Interference: A Principle Maintained. Contemporary South East Asia Journal, http://www.highbeam.com Accessed October 2, 2010

Rourke, Breffni O'. (2006). China: Africa Trade Offensive Part of Global Expansion. http://www.radiofreeeurope.com Accessed August 10, 2006

Sautman, B. and Hairong, Y. (2007), Friends and Interests: China's Distinctive Links with Africa in African Studies Review, Vol.50, No.3

Segal, Gerald. (1992). China and Africa. Annals of the American Academy of Political and Social Science, Vol.519, China's Foreign Relations, pp.115-126, http://www.jstor.org Accessed June 5, 2008

Shinn, S. David. (2007). Africa, China, United States and Oil. CSIS African Policy Forum. http://www.csis.org Accessed April 4, 2006

Susu, Xing. (2006). Sino-African cooperation in the 21st Century: A Strategic Partnership. Foreign Affairs Journal, The Chinese People's Institute of Foreign Affairs, June, No.80

Tareq Y. Ishmael, (1971). The People's Republic of China and Africa. The Journal of Modern African Studies, Vol. 9, No.4, pp.507-529 http://www.jstor.org Accessed May 8, 2007

Thang, Duc Nguyen. (n.d). Nature of the Theory "Human Rights Rank Above State Sovereignty" http://www.presscenter.org.vn Accessed August 18, 2010

Thompson, Drew. (2006). China's Emerging Interests in Africa: Opportunities and Challenges for Africa and the United States. African Renaissance Journal

Thompson, J.P. (2007). China's Crucial Role in Africa. Africafiles/At Issue Ezine. http://www.africafileatissueezine.com Accessed January 18, 2008

Tjonneland, Elling N, Bjorn Brandtzeag, Ashild Kolas, and Garth le Pere. (2006). China in Africa: Implications for Norwegian Foreign and Development Policies. Available at www.cmi.no/publication. Accessed August 15, 2008

Tull, Denis. (2008). China in Africa: Europeans Perceptions and Responses to the Chinese Challenge. School of Advanced International Studies. http://www.sais-jhu.edu/academics/regional-studies/africa Accessed February 10, 2010

Watts, Jonathan and Meldrum, Andrew. (2005). 'Mugabe Finds Succour in Beijing Deals.' The Guardian, July 27, http://www.guardian.co.uk Accessed August 5, 2005

Wood, Micheal. (2007). The Principle of Non-Interference in Contemporary International Law: Non-Interference in a State's Internal Affairs Used to be a Rule of International Law; Is it Still? A Summary of the Chatham House International Law Discussion Group Meeting Held on 28 February 2007 